\title{
Meat content and chemical composition of EL Gash sheep
}

\begin{abstract}
The study was conducted to evaluate the composition of meat content of EL Gash sheep, by studying, their carcass characteristic and analysis the components under their natural habitat. Meat was analyzed on fresh bases for determination of proximate chemical composition. The result indicated that moisture was $75.6 \pm 0.45$ in male and $73.9 \pm 0.45$ in female the ash was $1.02 \pm 0.02$ in the male and $1.19 \pm 0.02$ in the female The average means of the either extract [E.E] in the female was $2.37 \pm 0.09$ while in male was $1.20 \pm 0.09$ but the average mean of crude protein in the male was $20.6 \pm 0.23$ while in the female was $20.4 \pm 0.23$ the result indicated that the chemical composition EL Gash sheep of Either extract and moisture were significant while the crude protein and Ash were not significant and the percentage of the moisture was higher in male. But the crude protein was slightly high in male while the either extract [E.E] and the Ash were higher in the female.
\end{abstract}

Volume 6 Issue 4 - 2018

Omer MOM,' Ekhlas AN²

'Ministry of Agriculture and Animal Resources, University of Kassala, Sudan

${ }^{2}$ Department of Animal Production, Sudan University of Science and Technology, Sudan

Correspondence: Omer MOM, Ministry of Agriculture and Animal Resources, Eastern State-Kasala, Sudan, Tel 0 I I 1881684, Email ofathi42@yahoo.com

Received: July 30, 2018 | Published: August 272018

Keywords: meat content, chemical, composition, EL Gash

\section{Introduction}

The composition of meat were contain $75 \%$ of water, $19 \%$ of protein, $3.5 \%$ of solvable non protein, $2.5 \%$ of lipid, in organic component such as phosphorus, potassium, sodium, magnesium and trace element comprise $0.65 \%$ of fresh meat, Vitamin in quantities minute (Lawrie, 1979). The values of water $67 \%$ protein $11.8 \%$ fat 11.2 and ash $1.2 \%$. ${ }^{1}$ Water 60.87 , protein $22.29 \%$, fat $7.09 \%$ and ash is $2.24 .{ }^{2}$ Also Gaili et al., ${ }^{3}$ reported that the values of water $48.32 \%$, protein $14.99 \%$, fat 32.78 and ash $0.8 \%$ in fattened of sheep while in un fattened animals will be as the following water were $62.08 \%$, protein $20.93 \%$, fat $15.99 \%$ and ash $1.00 \%$. The feeding, age, species had highly significant effects on moisture, protein and fat in meat. Although the effect was not significant on ash, young animals had more ash in meat than older, ash in fattened animals was lower than in un fattened.

\section{Material and method}

Evaluation of carcass yield, characteristic and composition were done at Kassala town abattoir. Thirty, sheep, 15 males and 15 females, were purchased form the local market. Each sex was comprised of five groups, according to the age studied, More than 150gm of the each sample of the carcass were be taken in cooler content with ice and then transferred to the Khartoum university lab where the analysis composition component were be taken.

\section{Moisture content determination}

Determination of moisture content was based on weight loss from a definite quantity of meat, dried overnight in drying oven at $102^{\circ} \mathrm{C}$. The dried sample was cooled in a desiccators and weighted. The moisture content was calculated as a percentage of fresh sample weight as follows.

$$
\text { Moisture } \%=\frac{(\text { Weight of fresh sample }- \text { Weight of dried sample })}{\text { Weight of fresh sample }} \times 100
$$

\section{Protein content determination}

Crude protein content was determined by using Kjeldahl method and calculated by multiplying the amount of nitrogen by 6.25 . One gram of dried sample was weighed in Kjeldahl flasks. Half a tablet of catalyst mixture 10 parts $\mathrm{K}_{2} \mathrm{SO}_{4}$ to part of $\mathrm{CuSO}_{4}$ and $10 \mathrm{ml}$ of $\mathrm{H}_{2} \mathrm{SO}_{4}$ concentration were added. The content of the flask was digested under boiling at maximum heat for 2 hours, and then the flask was cooled and transferred to distillation unit. The simple was distilled by using $\mathrm{NaOH}$ solution $40 \%$. The content was titrated against HCL acid $0.1 \mathrm{~N}$ and crude protein percentage calculated as follows.

$$
\text { Crude protein } \%=\frac{(N \times T \times 0.0014 \times 20 \times 100 \times 6.25)}{\text { Weight of sample }} \times 100
$$

\section{Ether extract determination}

Fat content was determined by ether extract method. Tow grams of dried sample was placed in soxhellet tubes. The samples were subjected to continuous extractions with $250 \mathrm{ml}$ petroleum ether for 5hours. The flasks were then removed from the extractor and allowed to dry for 2 hours in a drying oven until no traces of other remained. The flasks were weighed after cooling in a desiccators. The difference between the flasks containing the fat and the weight of the empty flasks was the fat weight in the samples. The calculation was performed using the formula:

$$
\text { Fat } \% \text { of sample }=\frac{(\text { Fat Weight })}{\text { Weight of sample }} \times 100
$$

\section{Ash content determination}

Ash content was determined by weighing two grams of dried fat free sample into dried of known weight. The crucibles were placed inside a muffle furnace at $55^{\circ} \mathrm{C}$ for 18 hours, cooled in a desiccators and weighed to determine the ash percentage as follows:

$$
\text { Ash }=\frac{(\text { Weight } \text { of } \text { Ash })}{\text { Weight of sample }} \times 100
$$

\section{Statistical analysis}

Data were analyzed by using SPSS version (13) analysis of variance compared by Duncans multiply range test computer program. 


\section{Result and discussion}

Table 1 shows data related to chemical composition of El Gash sheep. The moisture was $75.6 \pm 0.45 \%$ in male and $73.9 \pm 0.45 \%$ in female this was agreed with (Lawrie 1979). Who reported that The composition of meat contain were $75 \%$ of water and was high than reported by El Tayeb et al. ${ }^{1}$ Who said The values of water in composition of meat was $67 \%$ While the composition of ash in this study were $1.02 \pm 0.02 \%$ in the male and $1.19 \pm 0.02 \%$ in the female this similar with Gaili et al. ${ }^{3}$ Who reported that the ash in composition of meat was $1.00 \%$, and typical with El Tayeb et al. ${ }^{1}$ Who observed that ash in composition of meat were $1.2 \%$. The average means of the either extract (E.E) of El Gash sheep in the female was $2.37 \pm 0.09 \%$ while in male of was $1.20 \pm 0.09 \%$ this result was on line with El Tayeb et al. ${ }^{1}$ Who reported that the composition of meat were contains $75 \%$ of water, $19 \%$ of protein, $3.5 \%$ of solvable non protein, $2.5 \%$ of lipid but the average mean of crude protein in the male was $20.6 \pm 0.23 \%$ while in the female was $20.4 \pm 0.23 \%$ the result were agreed with Gaili et al. ${ }^{3}$ Who Reported that the values of water were $62.08 \%$, protein $20.93 \%$, fat $15.99 \%$ and ash $1.00 \%$. The result indicated that the chemical composition of both extract and moisture were significant while the crude protein and Ash were not significant and we found that the percentage of the moisture was higher in male than the female But the crude protein was slightly high in male. While the either extract [E.E] and the Ash were higher in the female than the male.

Table I It shows the chemical composition of El Gash sheep

\begin{tabular}{llll}
\hline Items & Males\% & Females\% & Significant level \\
\hline Moisture & $75.6 \pm 0.45$ & $73.9 \pm 0.45$ & $\mathrm{~S}$ \\
Ash & $1.02 \pm 0.02$ & $1.19 \pm 0.02$ & N.S \\
E.E & $1.20 \pm 0.09$ & $2.37 \pm 0.09$ & S \\
C.P & $20.6 \pm 0.23$ & $20.4 \pm 0.23$ & N.S \\
\hline
\end{tabular}

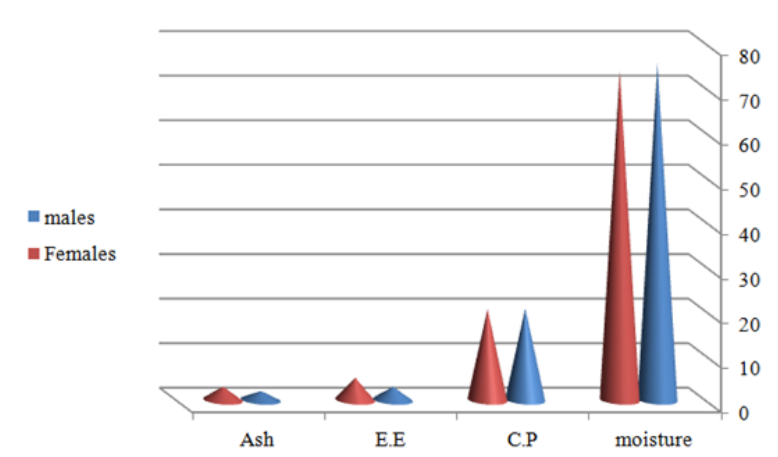

Figure I Chemical composition of El Gash sheep.

E.E, Either extract; Cp, crude protein.

\section{Acknowledgements}

None.

\section{Conflicts of interest}

Author declares that there is none of the conflicts.

\section{References}

1. El Tayeb AE, Nour EL Din AA, Tibin IM. Effect of two different roughages to concentrate ration on carcass trails of Sudan Desert sheep Sudan. J vet Sci and Anim husb. 1987;26(1):83-90.

2. El Tayeb EA. The effect of the sorghum gluten feed level on performance and carcass characteristic of growing lambs Sudan. Jvet Sci Anim Husb. 1991;3(2):1-6.

3. Gaili ESE, Chanen YS, Mukhtar AM. A comparative Study of some carcass characteristic of Sudan Desert Sheep and goats. Anim Prod. 1972. 